\title{
ESTIMASI POTENSI KARBON SEDIMEN MANGROVE PADA HUTAN ALAM DAN HUTAN REHABILITASI DI TAMAN HUTAN RAYA NGURAH RAI BALI
}

\author{
Clara Rosy Irawati ${ }^{* *}$, I Nyoman Merit ${ }^{2)}$, I Made Sudarma ${ }^{3)}$ \\ ${ }^{1)}$ Balai Pengendalian Perubahan Iklim dan Kebakaran Hutan dan Lahan Wilayah JabalNusa \\ ${ }^{2)}$ Program Studi Magister Ilmu Lingkungan, Pascasarjana, Universitas Udayana \\ ${ }^{3)}$ Program Studi Doktor Ilmu Lingkungan, Pascasarjana, Universitas Udayana \\ *Email: fregattaariel@gmail.com
}

\section{ABSTRACT \\ ESTIMATION OF POTENTIAL CARBON SEDIMENTS OF MANGROVE IN NATURAL FORESTS AND FOREST REHABILITATION AT NGURAH RAI GRAND FOREST PARK, BALI}

Sediments play an important role in coastal ecosystems. Apart from being a growing medium, sediment is also a place for accumulation and storage of various components including carbon. Ngurah Rai Forest Park is the largest mangrove in Bali with a large potential for sediment carbon stocks. To determine the carbon storage of mangrove sediments in natural forest and rehabilitation forest and the relationship between diameter size and vegetation type to sediment carbon in two forest types, a study was conducted using purposive sampling method based on canopy density level with three repetitions with a plot size of $10 \mathrm{mx}$. 10 meters. Sampling was divided into three depths, namely 0-30 cm, 31-60 cm and $61-100 \mathrm{~cm}$. The total carbon content of mangrove sediments in natural forest is $363,491.17 \mathrm{Mg} \mathrm{C}$ or equivalent to $363,491.17$ tons $\mathrm{C}$ and rehabilitation forest is $160,401.33$ $\mathrm{Mg} \mathrm{C}$ or equivalent to $160,401.33$ tons $\mathrm{C}$. The total sediment carbon content in Ngurah Rai Forest Park is $523,892.50 \mathrm{Mg} \mathrm{C}$ or equivalent to $523,892.50$ tons $\mathrm{C}$. Tree diameter had no significant effect on sediment carbon content, while vegetation type significantly affected sediment carbon content. Sonneratia alba had a significant negative effect on natural forests, while Rhizophora stylosa had a significant positive effect on rehabilitation forests. The results of the study suggest that it is necessary to maintain the preservation of mangroves and carry out rehabilitation in damaged areas. To increase the carbon content of sediments in mangrove forests, consider selecting the type of vegetation Rhizophora stylosa for the implementation of rehabilitation activities, because the type of Rhizophora stylosa makes a positive contribution to increasing the carbon content of sediments, with a note that the rehabilitation location is suitable for Rhizoporaceae species.

Keywords: Mangrove; Nature Forest; Rehabilitation; Sediment.

\section{PENDAHULUAN}

Pembangunan di wilayah pesisir merupakan salah satu penyebab berkurangnya luas hutan mangrove di
Indonesia selain aktivitas penebangan dan budidaya perikanan darat (tambak) yang berlebihan. Kawasan tropis merupakan habitat yang cocok bagi mangrove untuk tumbuh dan mendukung ketersediaan jasa ekosistem seperti siklus hara dan perikanan. 
Kontribusi hutan mangrove dalam menurunkan emisi karbon di atmosfer sangat besar namun akibat luas hutan mangrove yang terus berkurang sehingga besarnya emisi karbon yang dilepaskan belum diketahui secara pasti dikarenakan kurangnya data jumlah karbon sedimen dalam ekosistem ini (Donato et al., 2011).

Karbon sedimen adalah karbon yang berasal dari seluruh bahan organik pada tanah yang diambil dengan kedalaman tertentu meliputi akar maupun serasah berukuran kecil dengan diameter tidak mencapai $2 \mathrm{~mm}$ (IPCC, 2006). Sedimen berperan sebagai media tumbuh dan tempat berbagai komponen termasuk karbon tersimpan dan terakumulasi. Kemampuan sedimen dalam menyimpan karbon di ekosistem pesisir diperkirakan di atas $50 \%$ (Donato et al., 2011). Hal ini sejalan dengan pendapat dimana karbon yang tersimpan pada sedimen di area mangrove memiliki kecenderungan lebih besar daripada jenis hutan lainnya. Bahan organik yang terakumulasi pada sedimen mangrove berasal dari guguran daun dan ranting vegetasi mangrove dan terdekomposisi dengan bantuan mikroorganisme (Susiana, 2011). Ekosistem mangrove, lamun dan rawa merupakan karbon biru yang diperkirakan memiliki kemampuan 50-99 \% untuk menyimpan karbon dalam tanah. Kemampuan tanah menyimpan karbon bertahan hingga ribuan tahun dan mencapai kedalaman sampai enam meter dari permukaan tanah.

Di kawasan Tahura Ngurah Rai, ditemukan 33 species Mangrove yang terdiri dari 18 mangrove sejati dan 15 mangrove asosiasi (Hatori, 2004). Taman Hutan Raya Ngurah Rai terbentang dari Sanur-Nusa Dua. Berdasarkan tipe vegetasi, Tahura terbagi menjadi 2 (dua) yaitu vegetasi alam (hutan alam) dan hasil rehabilitasi (hutan rehabilitasi). Vegetasi alam didominasi oleh spesies Sonneratia alba, sedangkan hasil rehabilitasi didominasi oleh Rhizophora spp.
Tahura Ngurah Rai sebagai kawasan mangrove terbesar di Pulau Bali yang memiliki luas $\pm 1.373,5 \mathrm{Ha}$ dengan kondisi yang bertutupan vegetasi seluas 1.002,22 ha yang terdiri dari hutan alam seluas 725,36 ha dan hutan rehabilitasi seluas 276,86 ha (Pratama etal., 2019). Hutan alam mencapai kondisi klimaks pada pertumbuhan vegetasinya, dengan sedikit bantuan manusia (Arief, 2001). Hutan alam di Tahura Ngurah Rai didominasi oleh species Sonneratia alba, sedangkan hutan rehabilitasi dalam pertumbuhan vegetasinya memerlukan banyak bantuan manusia (Arief, 2001). Hutan rehabilitasi juga dapat diartikan sebagai hutan yang terbentuk sebagai hasil dari penanaman pohon yang dilakukan oleh manusia. Hutan rehabilitasi Tahura Ngurah Rai didominasi oleh Rhizophoraceae (Rhizophora mucronata, $R$. stylosa, $R$. apiculata). Penelitian ini bertujuan untuk menganalisis simpanan karbon sedimen dan menganalisis hubungan antara ukuran diameter pohon dan jenis vegetasi dengan simpanan karbon sedimen pada hutan alam dan hutan rehabilitasi di Tahura Ngurah Rai, Bali.

\section{METODOLOGI}

\subsection{Waktu dan Lokasi Penelitian}

Penelitian dilaksanakan dari Januari sam pai Mei 2021. Pengambilan data di lapangan dilaksanakan pada Januari hingga Maret 2021 selanjutnya analisis sampel sedimen dilaksanakan di Laboratorium dan pengolahan data dilakukan pada Februari sampai Mei 2021. Penelitian dilakukan di hutan hasil rehabilitasi dan hutan alam mangrove Tahura Ngurah Rai dengan mengambil sampel sedimen di lokasi penelitian. Peta lokasi pengambilan sampel dapat dilihat pada Gambar 1. 


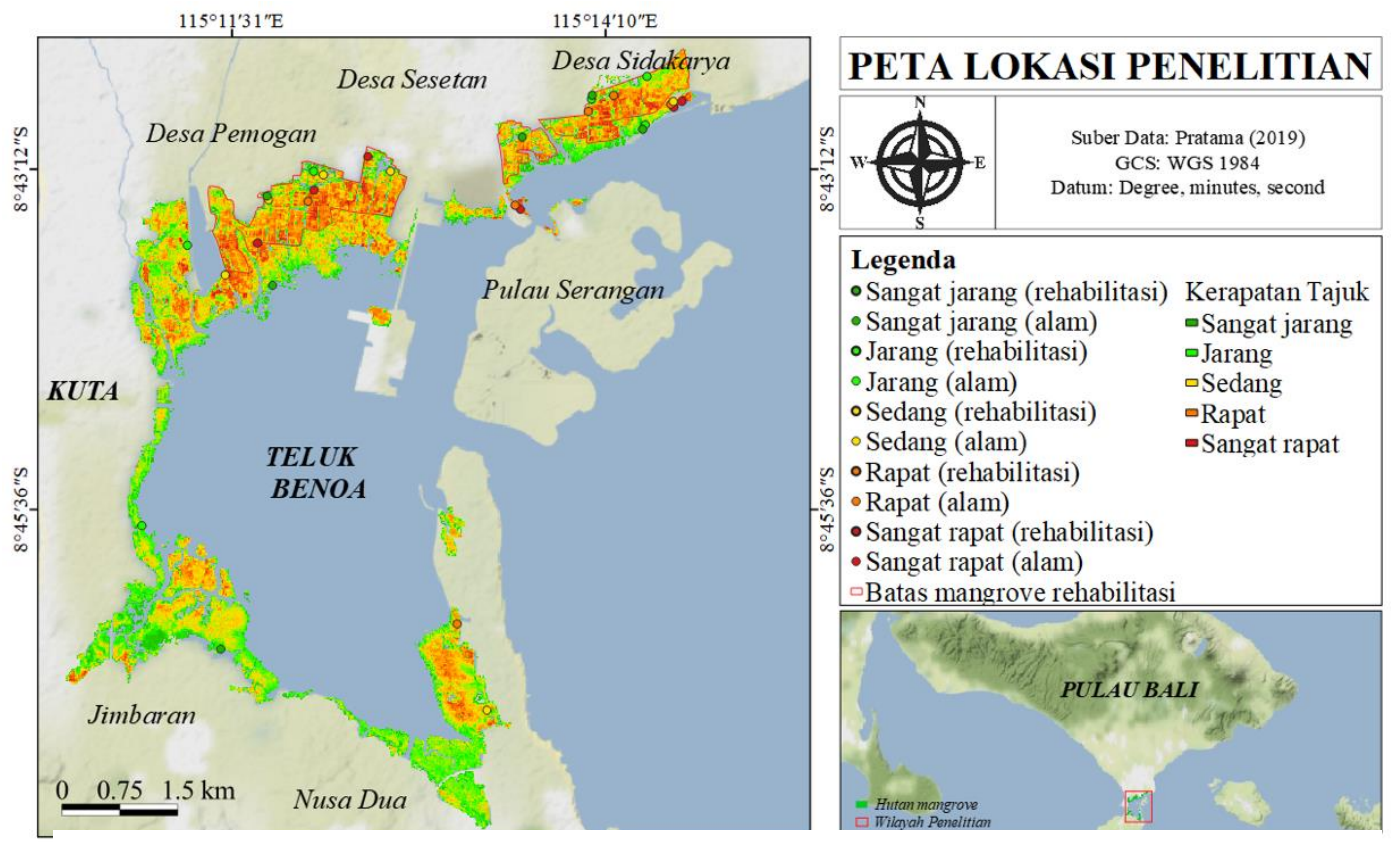

Gambar 1.

Peta Penelitian

Sumber: Pratama et al., (2019)

\subsection{Alat dan Bahan}

Peralatan yang digunakan beserta bahan dapat dilihat pada Tabel 1.

Tabel 1. Alat dan bahan

\begin{tabular}{ll}
\hline \multicolumn{1}{c}{ Instrumen } & \multicolumn{1}{c}{ Kegunaan } \\
\hline GPS & Menentukan koordinat \\
Corer & Mengambil sampel sedimen \\
pH meter & Mengukur tingkat ke asaman \\
Hagameter & Mengukur tinggi pohon \\
Refraktometer & Mengukur salinitas \\
Kompas & Mengukur azimuth/sudut \\
Peta Kerja & Menentukan lokasi plot \\
Aplikasi "Tides" & Mengetahui pasang surut \\
Parang & Membuat rintisan \\
Tally sheet & Tabel untuk mecatat data \\
Alat Tulis & Untuk menulis \\
Kamera & Dokumentasi \\
\hline
\end{tabular}

\subsection{Teknik Pengambilan Sampel}

Sampel diambil dengan survei dan pengamatan dilanjutkan dengan mengambil sampel di lapangan. Pengambilan sampel difokuskan di bahan organik dalam tanah atau sedimen mangrove melalui metode Purposive Sampling dengan stratifikasi berdasarkan tingkat kerapatan tajuk dan kemudahan akses di lokasi penelitian (jalan raya, jalan setapak, tanggul, alur sungai dan lain-lain). Plot sampel dibuat pada vegetasi hutan alam dan hutan rehabilitasi dengan tingkat kerapatan (sangat jarang, jarang, sedang, rapat, sangat rapat) dan diulang masing-masing sebanyak 3 (tiga) kali sehingga jumlah plot sampel pengamatan sebanyak 30 plot. Ukuran plot yang digunakan $10 \mathrm{~m} \times 10 \mathrm{~m}$ (bentuk persegi). Pada plot sampel diambil contoh substrat 
pada 3 titik dan untuk pengujian laboratorim akan di mix. Adapun tahapan kerja pengambilan sampel substrat sebagai berikut:

a) Bersihkan permukaan tanah dari sampah organik dan daun hidup sebelum melakukan pengambilan sampel;

b) Masukkan corer ke dalam tanah secara vertikal sedalam 1 (satu) meter, buka corer kemudian putar perlahan sampai corer terisi sedimen sampai penuh dan corer di tutup kembali, lalu corer di angkat dengan hati-hati;

c) Pengambilan sampel untuk uji laboratorium dilakukan dengan cara memotong sampel secara horizontal pada 3 (tiga) kedalaman $(0-30 \mathrm{~cm}, 31-60 \mathrm{~cm}$, $61-100 \mathrm{~cm}$ ). Sedimen yang akan di uji di laboratorium diambil sebanyak $10 \mathrm{~cm}$, sedimen di kedalaman $10-20 \mathrm{~cm}$ mewakili $0-30 \mathrm{~cm}, 40-50 \mathrm{~cm}$ mewakili $31-60 \mathrm{~cm}, 75-$ $85 \mathrm{~cm}$ mewakili $61-100 \mathrm{~cm}$;

d) Masukkan sampel ke dalam kantong sampel yang telah disiapkan lalu beri label untuk memudahkan identifikasi dan analisis

Loss on ignition (LOI) merupakan metode analisis yang digunakan mengacu pada Howard et al., (2014) dengan tahapan analisis sebagai berikut:

a) Letakkan sampel sedimen pada cawan porcelain lalu keringkan dengan oven selama 48 jam pada suhu $60^{\circ} \mathrm{C}$.

b) Dengan menggunakan mortar, sampel kering dihaluskan hingga mencapai kondisi homogen setelah itu masukkan kembali ke dalam kantong sampel;

c) Ambil 3 (tiga) gram sampel dan tempatkan.dalam crucible porcelain untuk pembakaran pada suhu $450^{\circ} \mathrm{C}$ di muffle furnace. Pembakaran dilakukan dalam durasi 4 (empat) jam kemudian dilakukan penimbangan dan pencatatan berat sampel.

\subsection{Analisa Data}

Penghitungan serta analisa data meliputi densitas tanah, pengabuan kering, $\% \mathrm{C}$, kepadatan karbon, dan total kandungan karbon tanah. Untuk menghitung data tersebut digunakan rumus yang merujuk pada Howard et al. (2014):

a) Densitas tanah.

Bulk density atau densitas tanah dihitung menggunakan persamaan (1):

$\begin{aligned} & \text { Densitas tanah } \\ & \text { oven }- \text { dry mass }(\mathrm{g})\end{aligned}$
$=\frac{\text { sample volume }(\mathrm{cm} 3)}{\text { samplat }}$

Oven-dry mass

Massa sampel yang dikeringkan (gram). Sample volume $=\mathrm{Isi} /$ volume sampel $\left(\mathrm{cm}^{3}\right)$

b) Lost on Ignition (Pengabuan Kering)

Pengabuan kering diperoleh berdasarkan persamaan (2):

$\% \mathrm{BO}$

$=\left(\frac{W o-W t)}{W o} x 100.\right)$

$\%=$ Nilai persentase bahan organic BO sedimen yang hilang pada proses pembakaran

$\mathrm{Wo}_{\mathrm{O}}=$ Ukuran Berat awal (3 gram)

$\mathrm{Wt}=$ Berat.akhir.setelah.pembakaran (gram)

c) Menghitung $\% \quad \mathrm{C}$ mengacu pada persamaan (3):

$\% C$
$=\left(\frac{1}{1,724} x \% B O\right)$

$$
\begin{aligned}
\% \mathrm{C}= & \text { Persen } \\
& \text { kandungan karbon bahan sed } \\
& \text { imen organik } \\
1,724= & \text { Konstanta untuk mengkonve } \\
& \text { rsi } \% \text { bahan organik menjadi } \\
& \% \mathrm{C} \text { organik }
\end{aligned}
$$

d) Kepadatan karbon diperoleh menggunakan rumus (4):

Soil C Density

$=\% C x B D($ Densitas tanah $)$

e) Kandungan karbon pada tanah diestimasi dengan persamaan (5) :

Soil C $(\mathrm{Mg} / \mathrm{ha})$

$=B D x \operatorname{SDIX} \% \boldsymbol{C}$ 
SDI = Interval kedalaman sampel $(\mathrm{cm})$.

Data yang telah terkumpul di analisis secara statistik. Untuk uji hipotesis tujuan (1) apakah ada perbedaan simpanan karbon sedimen pada hutan alam dan hutan rehabilitasi mangrove Tahura Ngurah Rai, Bali akan dilakukan analisis dengan uji $\mathrm{Z}$. Persamaan uji Z sebagai berikut :

$\boldsymbol{Z}$

$=\left(\frac{\bar{x}-\mu o}{\sigma / \sqrt{n}}\right)$

Keterangan :

$\mathrm{Z}=$ nilai $\mathrm{Z}$ hitung

$\mathrm{X}^{-} \quad=$ rata-rata sampel

$\mu 0=$ rata-rata yang ditentukan terlebih dahulu nilainya

$\sigma \quad=$ standar devasi populasi

$\mathrm{n} \quad$ = banyaknya sampel

\section{HASIL DAN PEMBAHASAN}

\subsection{Total Kandungan Karbon Sedimen Mangrove Per Hektar}

Apabila dari hasil analisis pada tujuan (2) menunjukkan ada hubungan antara ukuran diameter dan jenis pohon dengan simpanan karbon sedimen maka analisis regresi linear berganda akan digunakan sebagai uji lanjutan dengan rumus berikut:

$Y^{\prime}=a+b X$

$=\boldsymbol{c D}$

Keterangan:

$\mathrm{Y}^{\prime}=$ Jumlah simpanan karbon sedimen (ton ha ${ }^{-1}$ )

$\mathrm{X}=$ Diameter pohon $(\mathrm{m})$

$\mathrm{D} \quad=$ Jenis vegetasi $(1=$ vegetasi dominan, $0=$ vegetasi lainnya)

$=$ Konstanta

$=$ Koefisien regresi

= Koefisien dummy

Total kandungan karbon sedimen mangrove per hektar berdasarkan tingkat kerapatan tajuk dan kedalaman sampel sedimen dapat dilihat pada Gambar 2.

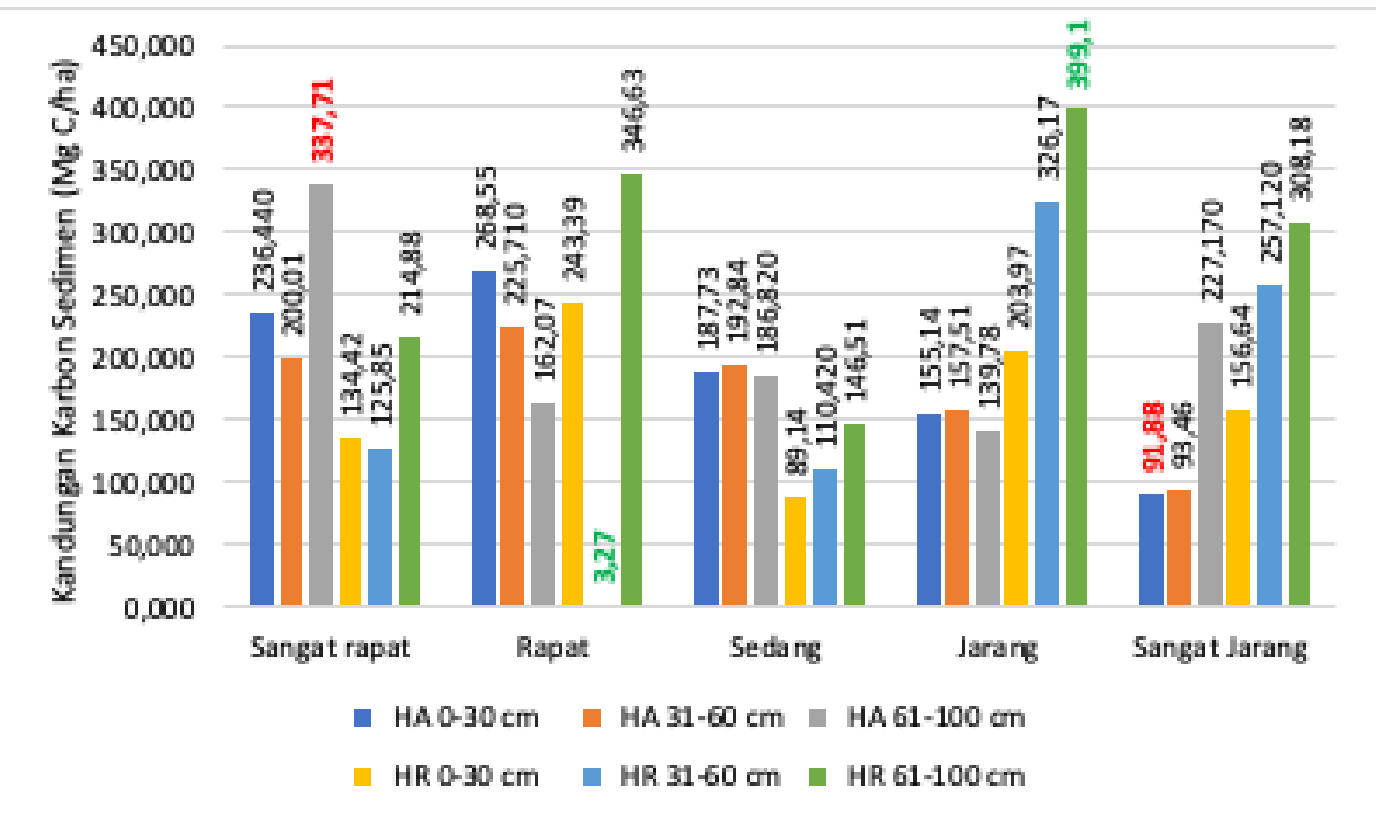

Gambar 2.

Histogram Total Kandungan Karbon Sedimen Mangrove Per Hektar Berdasarkan Tingkat Kerapatan dan Kedalaman Sampel Sedimen di Tahura Ngurah Rai 
Berdasarkan Gambar 2. total kandungan karbon sedimen mangrove per hektar tertinggi di hutan alam terletak pada kerapatan tajuk sangat rapat sebesar 337,71 $\mathrm{Mg}$ C/ha di kedalaman 61-100 $\mathrm{cm}$ dan terendah pada kerapatan tajuk sangat jarang sebesar $91,88 \mathrm{Mg} \mathrm{C} / \mathrm{ha}$ di kedalaman yang sama yakni $0-30 \mathrm{~cm}$. Untuk total kandungan karbon sedimen mangrove per hektar tertinggi di hutan rehabilitasi terletak pada kerapatan tajuk rapat sebesar 399,1 Mg C/ha di kedalaman 61-100 $\mathrm{cm}$ dan terendah pada kerapatan tajuk rapat sebesar 3,27 Mg C/ha di kedalaman 31-60 cm.

\subsection{Total Kandungan Karbon Sedimen Mangrove}

Untuk mengetahui total kandungan karbon sedimen mangrove perlu terlebih dahulu mengetahui luas hutan berdasarkan tingkat kerapatan tajuk dan kedalaman sampel sedimen di hutan alam dan hutan rehabilitasi. Total kandungan karbon sedimen mangrove berdasarkan tingkat kerapatan tajuk dan kedalaman sampel sedimen dapat dilihat pada Tabel 2.

Tabel 2. Total Kandungan Karbon Sedimen Mangrove Berdasarkan Tingkat Kerapatan Tajuk dan Kedalaman Sampel Sedimen

\begin{tabular}{|c|c|c|c|c|c|c|}
\hline \multirow[b]{2}{*}{$\begin{array}{c}\text { Kerapatan } \\
\text { Tajuk }\end{array}$} & \multicolumn{3}{|c|}{ Hutan Alam } & \multicolumn{3}{|c|}{ Hutan Rehabilitasi } \\
\hline & $\begin{array}{l}\text { Kandungan } \\
\text { karbon sedimen } \\
(\mathrm{Mg} \mathrm{C} / \mathrm{ha})\end{array}$ & $\begin{array}{l}\text { Luas } \\
\text { (Ha) }\end{array}$ & $\begin{array}{l}\text { Total Karbon } \\
\text { (Mg C) }\end{array}$ & $\begin{array}{c}\text { Kandungan } \\
\text { karbon sedimen } \\
(\mathrm{Mg} \mathrm{C} / \mathrm{ha})\end{array}$ & $\begin{array}{l}\text { Luas } \\
\text { (Ha) }\end{array}$ & $\begin{array}{c}\text { Total } \\
\text { Karbon } \\
(\mathrm{Mg} \mathrm{C})\end{array}$ \\
\hline Sangat Rapat & 774,160 & 2,03 & $1.571,54$ & 475,15 & 1,21 & 574,93 \\
\hline Rap & 656,330 & 43,85 & & 893,29 & 50,97 & $45.530,99$ \\
\hline Sedang & 567,390 & 206,55 & $117.194,40$ & 346,07 & 126,45 & $437.60,55$ \\
\hline Jarang & 452,43 & 344,11 & $155.685,69$ & 929,24 & 58,27 & $54.146,81$ \\
\hline Sangat Jarang & 412,510 & 146,08 & $60.259,46$ & 721,94 & 22,7 & $16.388,04$ \\
\hline Total & & 742,62 & $363.491,17$ & & 259,6 & $160.401,33$ \\
\hline Rata-rata & & & 489,47 & & & $\mathbf{6 1 7 , 8 8}$ \\
\hline
\end{tabular}

Berdasarkan Tabel 3. Total kandungan karbon sedimen mangrove pada hutan alam sebesar 363.491,17 Mg C atau setara 363.491,17 ton $\mathrm{C}$ dan pada hutan rehabilitasi sebesar $160.401,33 \mathrm{Mg} \mathrm{C}$ atau setara $160.401,33$ ton $\mathrm{C}$. Total kandungan karbon sedimen di Tahura Ngurah Rai sebesar 523.892,50 $\mathrm{Mg} \mathrm{C}$ atau setara $523.892,50$ ton $\mathrm{C}$.

\subsection{Hubungan antara Ukuran Diameter Pohon dan Jenis Vegetasi dengan Simpanan Karbon Sedimen pada Hutan Alam dan Hutan Rehabilitasi di Tahura Ngurah Rai}

Data rata-rata diameter pohon pada masing-masing tingkat kerapatan tajuk serta kandungan karbon sedimen rata-rata per plot sampel pada hutan alam dan hutan rehabilitasi di Tahura Ngurah Rai dapat dilihat pada Gambar 3.

Berdasarkan Gambar 3. Rata-rata diameter pohon terbesar pada tingkat kerapatan jarang sebesar $18,51 \mathrm{~cm}$ dengan kandungan karbon tertinggi sebesar 399,1 $\mathrm{Mg} \mathrm{C} / \mathrm{ha}$ yang terdapat pada hutan rehabilitasi dengan kedalaman $61-100 \mathrm{~cm}$. Sedangkan rata-rata diameter pohon terkecil pada tingkat kerapatan sedang sebesar 15,28 $\mathrm{cm}$ dengan kandungan karbon terendah sebesar 89,14 Mg C/ha yang terdapat pada hutan rehabilitasi dengan kedalaman 0-30 cm. 


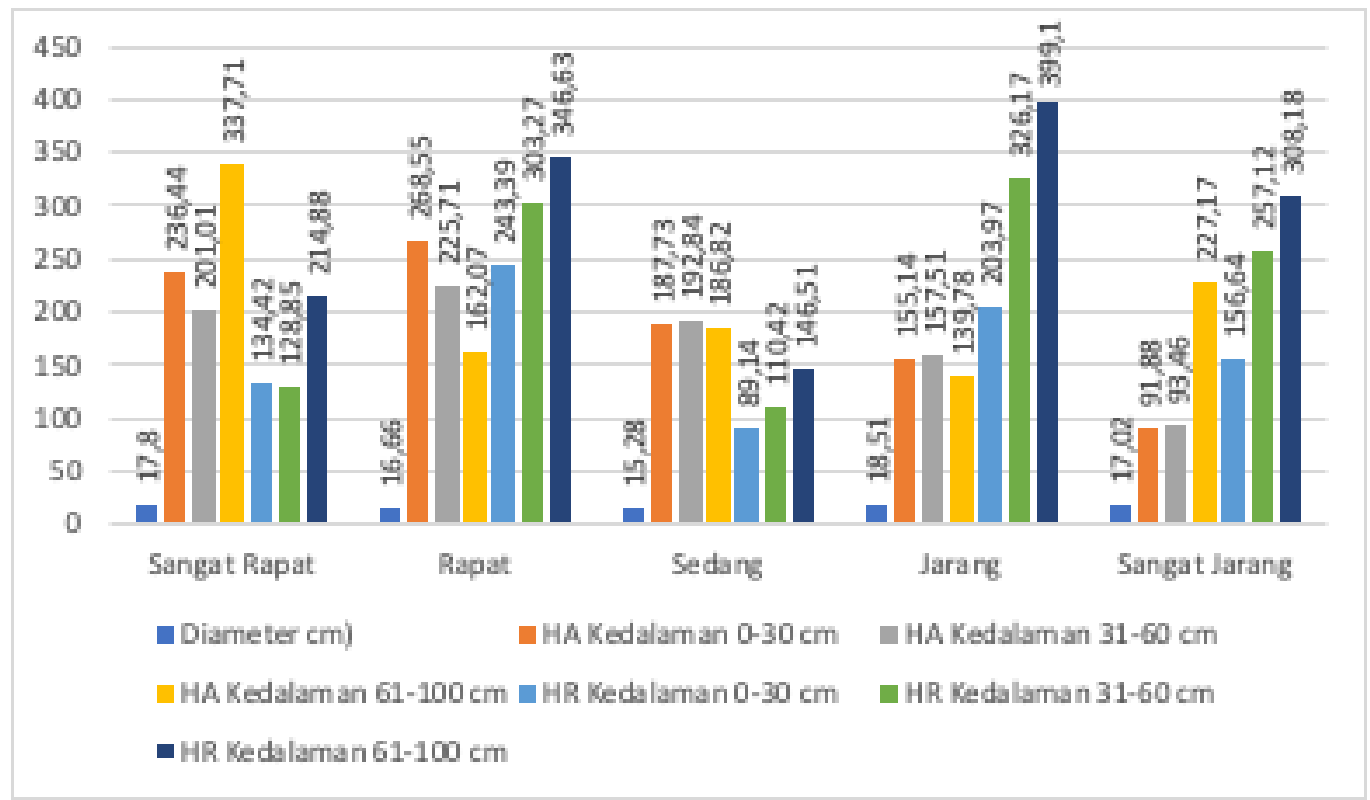

Gambar 3.

Histogram Rata-Rata Diameter Pohon pada Masing-masing Tingkat Kerapatan Tajuk serta Kandungan Karbon Sedimen Rata-rata per Hektar

\subsection{Simpanan Karbon Sedimen}

Berdasarkan output Tabel 3. dengan nilai signifikansi $0,00<0,05$, bermakna bahwa varians data heterogen untuk rerata kandungan karbon sedimen hutan alam dan hutan rehabilitasi. Selanjutnya untuk mengetahui apakah ada perbedaan yang nyata pada kandungan karbon sedimen di hutan alam dan rehabilitasi berpatokan pada nilai signifikansi (2-tailed) pada baris "Equal variances not assumed" dengan nilai 0,235> 0,05 yang bermakna bahwa nilai rerata karbon sedimen tidak berbeda nyata. Hasil uji statistik terhadap simpanan karbon sedimen Tahura Ngurah Rai dapat dilihat pada Tabel 3.

Tabel 3. Output Independent Samples Test Kandungan Karbon Sedimen pada Hutan Alam dan Hutan Rehabilitasi Tahura Ngurah Rai

Independent Samples Test

\begin{tabular}{|c|c|c|c|c|c|c|c|c|c|}
\hline & \multicolumn{2}{|c|}{$\begin{array}{l}\text { Levene's Test } \\
\text { for Equality of } \\
\text { Variances }\end{array}$} & \multicolumn{7}{|c|}{ t-test for Equality of Means } \\
\hline & \multirow[b]{2}{*}{$\mathrm{F}$} & \multirow[b]{2}{*}{ Sig. } & \multirow[b]{2}{*}{$\mathrm{t}$} & \multirow[b]{2}{*}{ df } & \multirow{2}{*}{$\begin{array}{c}\text { Sig. } \\
(2- \\
\text { tailed })\end{array}$} & \multirow{2}{*}{$\begin{array}{c}\text { Mean } \\
\text { Differenc } \\
\mathrm{e}\end{array}$} & \multirow{2}{*}{$\begin{array}{l}\text { Std. Error } \\
\text { Difference }\end{array}$} & \multicolumn{2}{|c|}{$\begin{array}{l}95 \% \text { Confidence } \\
\text { Interval of the } \\
\text { Difference }\end{array}$} \\
\hline & & & & & & & & Lower & Upper \\
\hline $\begin{array}{l}\text { Kandunga 'Equal } \\
\text { n Karbon } \\
\text { variances } \\
\text { assumed }\end{array}$ & 19.065 & .000 & -1.182 & 84 & .241 & $32.70472^{-}$ & 27.67046 & -87.73047 & 22.32103 \\
\hline $\begin{array}{l}\text { Equal } \\
\text { variances not } \\
\text { assumed' }\end{array}$ & & & -1.198 & 65.065 & .235 & 32.70472 & 27.29616 & -87.21790 & 21.80846 \\
\hline
\end{tabular}

Meskipun secara statistik tidak berbeda nyata, kandungan karbon sedimen hutan rehabilitasi Tahura Ngurah Rai sejumlah
224,60 MgC/ha lebih tinggi dari hutan alam dengan kandungan sebesar 191,89 MgC/ha. Nilai rerata karbon pada sedimen hutan alam 
tersebut melebihi kandungan karbon organik pada hutan alam di Perancak sebesar 185,97 Mg C ha-1 (Indraiswari dan Putra, 2018). Membandingkan.dengan penelitian serupa yang dilakukan oleh Mahasani etal. (2016) pada areal rehabilitasi mangrove di Taman Hutan Raya Ngurah Rai dimana total simpanan kandungan karbon organik sebesar 42.625.842,79 $\mathrm{Mg} \mathrm{C}$ dengan luas area penelitian $318,559 \mathrm{Ha}$ atau setara dengan 133.808,31 Mg C ha- ${ }^{1}$ maka kandungan karbon rata-rata per hektar di hutan rehabilitasi pada penelitian ini lebih kecil. Hal ini diduga karena adanya perbedaan kedalaman sampel dan luas area penelitian. Demikian pula bila dibandingkan dengan kandungan karbon organik di Papua Barat yang meliputi wilayah Bintuni, Teminabuan dan Timika secara berturut-turut sebesar 1.032 Mg C ha- ${ }^{1}$; $964,9 \mathrm{Mg} \mathrm{C}$ ha- $^{1}{ }^{\text {dan }} 674.9$ Mg Cha- ${ }^{1}$ (Taberima etal., 2014) maka kandungan karbon sedimen Tahura Ngurah Rai lebih kecil.

Rata-rata kandungan karbon sedimen pada hutan alam Tahura Ngurah Rai sebesar 191,89 Mg C ha- ${ }^{1}$ lebih kecil dari rata-rata kandungan karbon sedimen pada hutan rehabilitasi yang sebesar $224,60 \mathrm{Mg} \mathrm{C}$ ha- ${ }^{1}$. Hal tersebut diduga dipengaruhi oleh jenis substrat, lokasi plot dan pengaruh pasang surut. Pada hutan rehabilitasi substrat di dominasi oleh lumpur dengan lokasi pada zona tengah dengan pengaruh pasang surut yang tidak terlalu kuat sehingga kandungan karbon sedimen lebih besar. Namun pada hutan alam substrat dominan adalah pasir berlumpur dan berlokasi pada zona depan dengan pengaruh pasang surut yang lebih kuat sehingga kandungan karbon sedimen lebih kecil.

\subsection{Hubungan antara Ukuran Diameter dan Jenis Pohon dengan Simpanan Karbon Sedimen pada Hutan Alam}

Untuk mengetahui apakah diameter dan jenis pohon berpengaruh terhadap simpanan karbon sedimen pada hutan alam Tahura
Ngurah Rai, dilakukan analisis terhadap output uji statistic. Berdasarkan Tabel 4. di ketahui nilai $\mathrm{R}$ sebesar 0,347 yang bermakna korelasi yang "rendah" (Sugiyono, 2010) pada variabel diameter dan jenis pohon dengan kandungan karbon sedimen pada hutan alam. Kategori korelasi berdasarkan Sugiyono (2010) sebagai berikut.

Untuk membuktikan apakah korelasi atau hubungan tersebut berpengaruh signifikan (nyata) atau tidak terhadap kandungan karbon sedimen pada hutan alam, maka perlu menafsirkan output Coefficients seperti pada Tabel 5.

Berdasarkan Tabel 5. diperoleh nilai signifikansi untuk rata-rata diameter 0,570 > 0,05, artinya diameter tidak memiliki pengaruh signifikan atau nyata terhadap kandungan karbon sedimen pada hutan alam Tahura Ngurah Rai. Untuk nilai signifikansi jenis dominan $0,028<0,05$ bermakna bahwa jenis pohon berpengaruh signifikan atau nyata pada kandungan karbon sedimen pada hutan alam Tahura Ngurah Rai. Regresi kandungan karbon sedimen pada hutan alam sebagai berikut:

Kandungan Karbon HA $=171.052+3.098 \mathrm{X}$ ns - 61.141D*

$$
\begin{array}{ll}
\text { Keterangan : } & \mathrm{X}=\text { Diameter pohon }(\mathrm{cm}) \\
& \mathrm{D}=\text { Jenis Vegetasi }(1= \\
& \text { Sonneratia alba, } 0=\text { vegetasi } \\
& \text { lainnya }) \\
& \mathrm{ns}=\text { Non signifikan } \\
& *=\text { Nyata pada taraf } 5 \%
\end{array}
$$

Berdasarkan model persamaan regresi tersebut, diameter pohon (X) tidak berpengaruh nyata terhadap kandungan karbon sedimen pada hutan alam. Namun jenis vegetasi (D) berpengaruh nyata dengan koefisien penduga sebesar - 61.141. Tanda negatif pada peubah dummy dan bersifat nyata berarti bahwa kandungan karbon sedimen pada hutan alam dengan vegetasi Sonneratia alba lebih kecil dibandingkan dengan jenis vegetasi lainnya. 
Tabel 4. Output Model Summary Hubungan Diameter dan Jenis Pohon terhadap Kandungan Karbon Sedimen pada Hutan Alam Tahura Ngurah Rai

\begin{tabular}{|c|r|r|r|r|}
\hline Model & \multicolumn{1}{|c|}{ R } & R Square & Adjusted R Square & \multicolumn{1}{c|}{ Std. Error of the Estimate } \\
\hline 1 & $.347^{\mathrm{a}}$ & .120 & .075 & 79.51750 \\
\hline
\end{tabular}

a. Predictors: (Constant), Jenis Dominan, Rata-rata Diameter

\begin{tabular}{ll}
\hline & Kategori Korelasi \\
\hline $0.00-0.199$ & Sangat rendah \\
$0.20-0.399$ & Rendah \\
$0.40-0.599$ & Sedang \\
$0.60-0.799$ & Kuat \\
$0.80-1.00$ & Sangat Kuat \\
\hline
\end{tabular}

Sumber : Sugiyono (2010)

Tabel 5. Output Coefficients Hubungan Diameter dan Jenis Pohon terhadap Kandungan Karbon Sedimen Tanah pada Hutan Alam Tahura Ngurah Rai

Coefficients $^{\mathrm{a}}$

\begin{tabular}{|c|c|c|c|c|c|c|}
\hline \multirow{2}{*}{\multicolumn{2}{|c|}{ Model }} & \multicolumn{2}{|c|}{$\begin{array}{l}\text { Unstandardized } \\
\text { Coefficients }\end{array}$} & \multirow{2}{*}{$\begin{array}{c}\text { Standardized } \\
\text { Coefficients } \\
\text { Beta }\end{array}$} & \multirow[b]{2}{*}{$\mathrm{t}$} & \multirow[b]{2}{*}{ Sig. } \\
\hline & & B & Std. Error & & & \\
\hline \multirow[t]{3}{*}{1} & (Constant) & 171.052 & 88.440 & & 1.934 & .060 \\
\hline & Rata-rata Diameter & 3.098 & 5.411 & .094 & .573 & .570 \\
\hline & Jenis Dominan & -61.141 & 26.867 & -.374 & -2.276 & .028 \\
\hline
\end{tabular}

a. Dependent Variable: Kandungan Karbon Sedimen

\subsection{Hubungan antara Ukuran Diameter dan Jenis Pohon dengan Simpanan Karbon Sedimen pada Hutan Rehabilitasi}

Untuk mengetahui apakah diameter dan jenis pohon berpengaruh terhadap simpanan karbon sedimen pada hutan rehabilitasi Tahura Ngurah Rai, dilakukan analisis terhadap output uji statistik seperti Tabel 6 .
Nilai R $\quad(0,405) \quad$ pada Tabel 6. menunjukkan hubungan "sedang" (Sugiyono, 2010) antara diameter dan jenis pohon dengan kandungan karbon sedimen pada hutan alam. Untuk membuktikan korelasi atau hubungan tersebut berpengaruh signifikan (nyata) atau tidak terhadap kandungan karbon sedimen pada hutan rehabilitasi, maka perlu menafsirkan output Coefficients yang dapat dilihat pada Tabel 7.

Tabel 6. Output Model Summary Hubungan Diameter dan Jenis Pohon terhadap Kandungan Karbon Sedimen pada Hutan Rehabilitasi Tahura Ngurah Rai

Model Summaryb

\begin{tabular}{|c|c|c|c|c|c|c|c|c|c|c|}
\hline \multirow{2}{*}{ Model } & \multirow{2}{*}{$\mathrm{R}$} & \multirow{2}{*}{$\begin{array}{c}\mathrm{R} \\
\text { Square }\end{array}$} & \multirow{2}{*}{$\begin{array}{c}\text { Adjusted } \\
\text { R } \\
\text { Square }\end{array}$} & \multirow{2}{*}{$\begin{array}{l}\text { Std. Error of } \\
\text { the Estimate }\end{array}$} & \multicolumn{5}{|c|}{ Change Statistics } & \multirow[t]{2}{*}{$\begin{array}{l}\text { Durbin- } \\
\text { Watson }\end{array}$} \\
\hline & & & & & $\begin{array}{r}\text { R Square } \\
\text { Change }\end{array}$ & $\begin{array}{c}\mathrm{F} \\
\text { Change }\end{array}$ & df 1 & df 2 & $\begin{array}{l}\text { Sig. F } \\
\text { Change }\end{array}$ & \\
\hline 1 & $.405^{\mathrm{a}}$ & .164 & .123 & 152.14112 & .164 & 4.020 & 2 & 41 & .025 & 2.206 \\
\hline
\end{tabular}

a. Predictors : (Constant), VegHR, DiameterHR

b. Dependent Variable: KKHR 
Tabel 7. Output Coefficients Hubungan Diameter dan Jenis Pohon terhadap Kandungan Karbon Sedimen Tanah pada Hutan Rehabilitasi Tahura Ngurah Rai

Coefficients $^{\mathrm{a}}$

\begin{tabular}{|c|c|c|c|c|c|c|c|c|c|}
\hline \multirow{2}{*}{\multicolumn{2}{|c|}{ Model }} & \multicolumn{2}{|c|}{$\begin{array}{c}\text { Unstandardized } \\
\text { Coefficients }\end{array}$} & \multirow{2}{*}{$\begin{array}{c}\begin{array}{r}\text { Standardized } \\
\text { Coefficients }\end{array} \\
\text { Beta }\end{array}$} & \multirow[b]{2}{*}{$\mathrm{t}$} & \multirow[b]{2}{*}{ Sig. } & \multicolumn{3}{|c|}{ Correlations } \\
\hline & & B & Std. Error & & & & $\begin{array}{l}\text { Zero- } \\
\text { order }\end{array}$ & Partial & Part \\
\hline \multirow[t]{3}{*}{1} & (Constant) & 378.705 & 98.496 & & 3.845 & .000 & & & \\
\hline & DiameterHR & -21.197 & 10.549 & -.337 & -2.009 & .051 & -.095 & -.299 & -.287 \\
\hline & VegHR & 156.682 & 56.828 & .462 & 2.757 & .009 & .286 & .395 & .394 \\
\hline
\end{tabular}

a. Dependent Variable: KKHR

Berdasarkan Tabel 7. diperoleh nilai signifikansi untuk rata-rata diameter 0,051 $>0,05$ bermakna bahwa diameter pohon tidak memberikan pengaruh signifikan atau nyata pada kandungan karbon sedimen pada hutan rehabilitasi Tahura Ngurah Rai. Untuk nilai signifikansi jenis dominan sebesar 0,009 $<0,05$ yang berarti bahwa jenis pohon berpengaruh signifikan atau nyata terhadap kandungan karbon sedimen pada hutan rehabilitasi Tahura Ngurah Rai. Regresi kandungan karbon sedimen pada hutan rehabilitasi sebagai berikut:

Kandungan Karbon HR = $378.705-21.197 X$ ns $+156.682 D^{*}$

Keterangan : $\quad X=$ Diameter pohon $(\mathrm{cm})$

$$
\mathrm{D}=\text { Jenis Vegetasi }(1=
$$

Sonneratia alba, $0=$ vegetasi lainnya)

ns = Non signifikan

* = Nyata pada taraf 5\%

Makna model persamaan.regresi.tersebut yakni diameter pohon $(\mathrm{X})$ tidak berpengaruh nyata terhadap kandungan karbon sedimen pada hutan rehabilitasi. Namun jenis vegetasi (D) berpengaruh nyata dengan koefisien penduga sebesar +156.682 . Tanda positif pada peubah dummy dan bersifat nyata berarti bahwa kandungan karbon sedimen pada hutan rehabilitasi dengan vegetasi Rhizophora stylosa lebih besar dibandingkan dengan jenis vegetasi lainnya. dapat disimpulkan bahwa jenis Rhizophora stylosa memberikan sumbangan karbon sedimen yang lebih besar dibandingkan dengan jenis lainnya pada hutan rehabilitasi.

\section{SIMPULAN DAN SARAN}

\subsection{Simpulan}

1. Kandungan karbon sedimen per hektar pada hutan alam lebih kecil dibandingkan dengan hutan rehabilitasi. Nilai rata-rata kandungan karbon sedimen di hutan alam sebesar 489,47 Mg C dan di hutan rehabilitasi sebesar $617,88 \mathrm{Mg}$ C. Secara statistik rata-rata kandungan karbon sedimen di hutan alam dan hutan rehabilitasi tidak berbeda nyata.

2. Ukuran diameter tidak berpengaruh signifikan terhadap kandungan karbon sedimen baik pada hutan alam dan hutan rehabilitasi. Namun jenis mangrove berpengaruh nyata pada simpanan karbon sedimen, dimana pada hutan alam jenis Sonneratia alba memberikan sumbangan lebih kecil terhadap kandungan karbon sedimen dibandingkan jenis lainnya, sebaliknya di hutan rehabilitasi jenis Rhizophora stylosa memberikan sumbangan lebih besar terhadap kandungan karbon sedimen dibandingkan dengan jenis Rhizophora mucronata, Rhizophora apiculata dan Bruguiera gymnorrhiza.

\subsection{Saran}

1. Untuk menjaga fungsi mangrove sebagai penyerap karbon perlu mempertahankan kelestarian mangrove dan melakukan rehabilitasi pada kawasan yang rusak.

2. Untuk meningkatkan kandungan karbon sedimen pada hutan mangrove bisa 
mempertimbangkan pemilihan jenis Rhizophora stylosa untuk pelaksanaan kegiatan rehabilitasi, karena jenis Rhizophora stylosa memberikan sumbangan positif terhadap peningkatan kandungan karbon sedimen. Tentunya dengan catatan bahwa lokasi rehabilitasi cocok untuk jenis Rhizoporaceae

\section{DAFTAR PUSTAKA}

Arief, A. 2001. Hutan dan Kehutanan. Yogyakarta: Kanisius.

Donato, D. C., Kauffman, J. B., Murdiyarso, D., Kurnianto, S., Stidham, M., \& Kanninen, M. 2011. Mangroves among the most carbonrich forests in the tropics.

Nature Geoscience, 4(5):293-297.

Hatori, H. 2004. Eko-Tour Gaido Manual. The Mangrove Information Centre. Denpasar.

Howard, J., Hoyt, S., Isensee, K., Telszewski, M., Pidgeon, E. 2014. Coastal Blue Carbon: Methods for Assessing Carbon Srocks and Emission Factors in Mangroves, Tidal Salt Marshes, and Seagrass Meadows. Conservation Internasional, Intergovernmental Oceanographic Commission of UNESCO, Internasional Union for Conservastion of Nature. Virginia, USA.

Indraiswari, I.G.A.A.M., Putra, I.D.N.N. 2018.

Estimasi Persentase Karbon Organik p ada Tanah di Hutan Mangrove Alami, Perancak, Bali.

Journal of Marine Research and Technology 1(1),1-4.

IPCC. 2006. IPCC Guidelines for National Greenh ouse Gas Inventories, Prepared by the National Greenhouse Gas Inventories Programme,

Eggleston H.S.,
Buendia L., Miwa K., Ngara T. and Tanabe K. (eds). Japan: IGES.

Kauffman, J.B., Donato, D.C., 2012. Protocols for the measurement, monitoring and reporting of structure, biomass and carbon stocks in mangrov e forests. CIFOR Bogor, Indonesia: Working Paper 86.

Mahasani, I.G.A.I., Karang, I.W.G.A., Hendrawan, I.G. 2016. Karbon Organik di Bawah Permukaan Tanah pada Kawasan Rehabilitasi Hutan Mangrove, Taman Hutan Raya Ngurah Rai, Bali. Prosiding Seminar Nasional Kelautan 2016. Universitas Trunojoyo Madura.

Pratama, I.G.M.Y., Karang, I.W.G.A., Suteja, $\quad$ Y. 2019. Distribusi Spasial Kerapatan

Mangrove Menggunakan Citra Sentinel -2A Di TAHURA Ngurah Rai Bali. Journal of

Marine and Aquatic Sciences 5(2), 192-202.

Sugiyono. 2010. Metode Penelitian Kuantitatif, Kualitatif, dan R\&D. Bandung: Alfabeta, CV.

Susiana. 2011. "Diversitas dan Kerapatan Mangrove, Gastropoda dan Bivalvia di Estuari Perancak, Bali”. (Skripsi). Program Studi Manajemen Sumberdaya Perairan Jurusan Perikanan Fakultas Ilmu Kelautan dan Perikanan Universitas Hasanuddin, Makassar.

Taberima, S., Nugroho, Y.D., Mudiyarso, D. 2014. The Distribution of Carbon Stock in Selected Mangrove Ecosystem of Wetlands Papua: Bintuni, Teminabuan, and Timika Eastern Indonesia. International Conference on Chemical, Environment \& Biological Sciences (CEBS-2014) Sept. 17-18, 2014 Kuala Lumpur (Malaysia). 